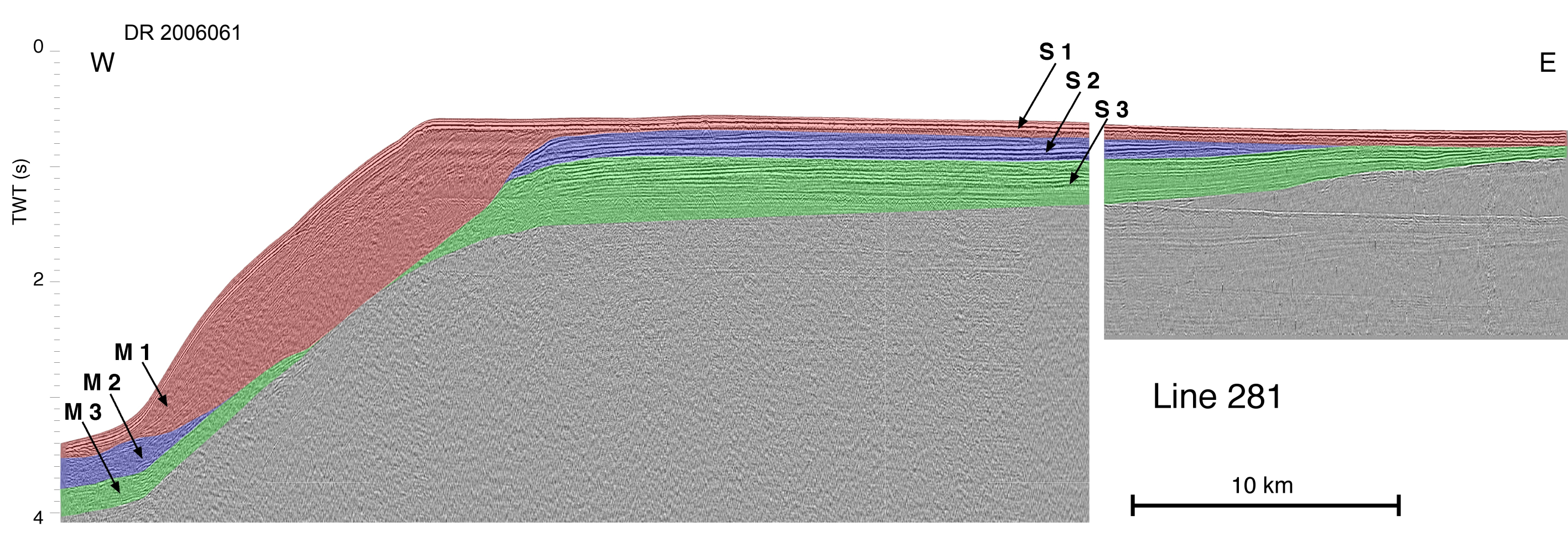

Rebesco et al. Data repository item 1 


\section{Rebesco et al.} Data repository item 2 